\title{
The Effect Of Gender And Knowledge On Students' Impressions Of Accountants In The Post-Enron Era
}

Steven C. Hunt, Western Illinois University, USA

Robert C. Intrieri, Western Illinois University, USA

A. Anthony Falgiani, Western Illinois University, USA

Marie T. Papini, Counselor, Watertown Elementary School, TN, USA

\begin{abstract}
This study examines college students' impressions of accountants from various sources. It extends previous research on students' impressions of accountants by analyzing impressions after Enron, gender differences in impressions, and the effect of knowledge on impressions and adding news reports as an impression source. Students rated their impressions of accountants when they selected a major on each of 30 characteristics (such as ethical, versatile, and exciting) from each of four sources, plus a general rating. When qualities were combined into two factors, Professionalism and Personability, accountants were seen as professional, but not particularly personable. In many areas, finance majors had impressions of accountants equal to or higher than those of accounting students, while other majors had significantly lower impressions of accountants. News reports did not significantly influence students' views of accountants. Knowledge was strongly correlated with impressions. Accounting students had the lowest knowledge of accountants from news reports and movies/TV of any major. Females held more positive impressions of accountants than did males. Implications for various groups, including college and high school accounting education and the accounting profession, are discussed.
\end{abstract}

Keywords: Impressions of accountants, accounting students, gender, factor analysis

\section{INTRODUCTION}

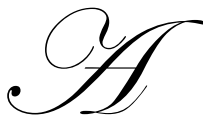

ccountants provide invaluable information and analysis to many groups, such as investors, creditors, and organization managers. In recent years, financial scandals have enveloped Enron, WorldCom, HEALTHSOUTH, Xerox, and other companies. Widespread public anger over the actions of accountants and auditors of those and other companies led to increased regulation of accounting and auditing. The Sarbanes-Oxley Act (SOX) and the creation of the Public Companies Accounting Oversight Board were designed to restore confidence in corporate financial information. The extent to which accountants are perceived as possessing positive qualities such as competence and ethics may affect public confidence in accountants and their work and influence the type of people choosing accounting as a profession.

There has been considerable concern in recent years that college accounting programs may attract students who view accounting as suited only to narrowly-focused technicians who enjoy routine tasks, while dissuading many others from considering accounting careers (Albrecht \& Sack, 2000; Davidson \& Etherington, 1995). However, accountants' roles have expanded dramatically as they do less scorekeeping and more problem-solving to help achieve business success (Siegel, Sorensen, \& Richtermeyer, 2003). Employers hire accountants who possess qualities necessary for advancement. For example, Chief Financial Officers are expected to be creative, motivating, energetic, versatile, and strong communicators (Myers, 2002).

Considerable research on selection of accounting majors (e.g., Chen, Jones, \& McIntyre, 2005; Saemann \& Crooker, 1999; Inman, Wenzler, \& Wickert, 1989; Paolillo \& Estes, 1982) has examined students' impressions of 
various aspects of the accounting profession, such as working conditions. Coleman, Kreuze \& Langsam (2004) and Saemann, Crooker \& Kreissl (2007) examined perceptions of the accounting profession in the wake of accounting scandals. However, it is also necessary to examine students' impressions of accountants themselves. Individuals may use stereotypes to choose or reject careers in accounting, by considering how they might feel about themselves or coworkers if they selected that career (Gottfredson, 1981; DeCoster, 1971).

Determining impressions of accountants held by those majoring in other subjects is important. Since accounting programs may compete with finance for the same students, knowing finance majors' impressions of accountants may help in devising ways to attract desirable students into accounting. Also, since other business majors will work with accountants, overcoming the former's negative stereotypes is necessary for accountants to rise to leadership positions commensurate with their abilities.

\section{LITERATURE REVIEW AND DEVELOPMENT OF RESEARCH QUESTIONS}

A common stereotype of accountants includes "impersonal,...inflexible, orderly, and introverted" (DeCoster, 1971, p. 40) and "cautious, methodical, systematic, anti-social and... boring!" (Parker, 2000, p. 50). While not completely negative, this stereotype may not reflect qualities required of today's accountants (Bougen, 1994; Imada, Fletcher, \& Dalessio, 1980).

One source of impressions of accountants is their fictional portrayal, in film and television. Dimnik \& Felton (2000), Holt (1994), Beard (1994), and Smith \& Briggs (1999) found that accountants were presented in films as lacking in communication skills and ethics. However, these qualities are considered essential by the accounting profession (Tie, 2003; Hermanson, Hermanson, \& Ivancevich, 1995).

Such fictional portrayals of accountants as conniving and socially challenged can be mitigated by impressions from other sources, such as actual accountants known (Cory, 1992). By examining accountants' personalities, Davidson \& Etherington (1995) and DeCoster \& Rhode (1971) found that the stereotype of accountants was inaccurate. For example, the latter found that accountants employed at CPA firms ranked much higher on sociability than the traditional stereotype would predict.

Another potential source of impressions is an introductory accounting course. Typically required for all business majors, this course provides a major opportunity for educators to attract quality students to accounting (Cohen \& Hanno, 1993; Geiger \& Ogilby, 2000; Chen, et al., 2005). Coate, Mitschow, Schinski, \& Colson (2003) found that students in accounting principles classes viewed accountants as being more prudent, conscientious, and emotionally stable than the average person (positive aspects of a common stereotype), but also less flexible, imaginative, and likable (negative aspects).

Accounting majors may not fully hold the stereotype of accountants. Hermanson et al. (1995) found that accounting majors better understood the need for accountants to possess creativity and communication skills than did non-accounting majors.

The previously mentioned studies each examined one source of impressions. In contrast, Hunt, Falgiani, \& Intrieri (2004) examined college students' impressions of accountants from three sources (movies/TV, accounting courses, and accountants the students had known) and overall impressions. Factor analysis reduced 58 possible qualities of accountants into two distinct factors, labeled Professionalism and Personability. Consistent with prior research, accountants were perceived as professionally competent but interpersonally deficient. In contrast to prior research, movies/TV resulted in neutral impressions of accountants. Accounting courses provided the least favorable impressions. Finance majors had the lowest impressions of accountants. Subjects' impressions were obtained prior to the reporting of the Enron scandal. The relative importance of sources of impressions on overall impressions was not examined.

The current study examines three major issues. First, what impressions of accountants did university students have at the time of selecting a major? This study extends previous research by examining such impressions 
of accountants following Enron, adding another source of impressions (news reports of accountants), and determining the relative importance of each source on overall impressions. This leads to research question 1.

RQ1a: What impressions do students have of accountants from various sources, as well as overall impressions?

RQ1b: What differences exist in impressions of accountants between accounting majors and students in other disciplines?

RQ1c: What is the relative importance of various sources of impressions of accountants on overall impressions?

Second, this study extends previous research by examining the effect of gender on impressions of accountants. Female accounting students comprise 57\% of accounting graduates (Vigilante, 2005). Therefore it is necessary to examine perceptions of accountants from their perspective. Lips (1992) found that females were less likely to hold occupational stereotypes. This research may provide a first step toward determining if the higher numbers of women in accounting programs reflect their holding better impressions of accountants.

Recent accounting scandals may have affected women's perceptions of accountants differently from men's. Several studies (St. Pierre, Nelson, \& Gabbin, 1990; Giacomino, Mitschow, Schinski, \& Colson, 1991; Ameen, Guffey, \& McMillan, 1996; Sankaran \& Bui, 2003) have shown women accounting students to be more highly developed ethically than men. However, this does not necessarily translate into more ethical behavior (Radtke, 2000). Thus, scandals may affect women's views of accountants and possibly their interest in accounting. This leads to research question 2 .

RQ2: What effect does gender have on impressions of accountants?

A third issue that extends previous research is the extent of student knowledge about accountants when they select a major and whether such knowledge influences impressions. One expects accounting majors to know more about accountants and the qualities they need to succeed. If knowledge affects impressions, greater knowledge of accountants should help dispel negative stereotypes and improve impressions of accountants. However, there is evidence that people use confirming hypotheses in career selection. They may then interpret new information in terms of previous stereotypes and discount disconfirming information (Skrypnek \& Snyder, 1982; Blustein \& Strohmer, 1987; Judd \& Park, 1993). This leads to the third research question.

RQ3a: What level of knowledge of accountants do students have from various sources?

RQ3b: What differences exist in levels of knowledge of accountants between accounting majors and those in other disciplines?

RQ3c: What is the relative importance of various sources of knowledge of accountants on overall knowledge?

RQ3d: What is the relationship between level of knowledge and impressions of accountants?

RQ3e: Does knowledge of accountants differ by gender?

\section{METHOD}

\section{Participants}

To provide for comparison with Hunt et al. (2004), participants were recruited from the same medium sized public university with AACSB accredited programs in Business and Accounting. An instrument was administered to a convenience sample of 344 students from Principles of Accounting I and II and a number of other business courses likely to be taken by sophomores or first semester juniors. These classes were chosen for three reasons. First, reaching students early in their business education should reduce influences from classes and increase students' ability to reflect upon their impressions of accountants at the time they chose a major. Second, a wide variety of students was obtained. Third, this approach facilitates comparison of results with Hunt et al. (2004). Participants completed various demographic questions, including age, gender, major, whether they had taken a high school accounting class, age at which they selected a major, and recency of that decision. 


\section{Impressions of Qualities of Accountants}

Participants rated the extent to which 30 items described their impression of accountants when they decided on a major. These qualities, listed in Table 1, comprised the factors of Professionalism and Personability in Hunt et al. (2004). These qualities were measured using a seven-point Likert scale (1= very inaccurate description; $7=a$ very accurate description). Participants rated each of the 30 items across five impression sources: Fictional Movies/TV, News Reports, Accountants You Knew, Accounting Courses, and All Sources. Some missing data resulted from students' not responding to items for a source about which they could not comment.

\begin{tabular}{|c|c|}
\hline \multicolumn{2}{|c|}{ Table 1 } \\
\hline Item Associated with Professionalism and Personability Factors \\
\hline Orofessionalism & Personability \\
\hline Ethical & Exciting \\
\hline Attentive to Detail & Outgoing \\
\hline Financially Successful & Admired \\
\hline Gives Good Business Advice & A Leader \\
\hline Analytic & Persuasive \\
\hline Professional & Witty \\
\hline Responsible & Charismatic \\
\hline Good at Math & Flamboyant \\
\hline Intelligent & Energetic \\
\hline Sensible & Versatile \\
\hline Competent & Unconventional \\
\hline Well-Dressed & \\
\hline Efficient & \\
\hline Knows Taxes & \\
\hline Thorough & \\
\hline Computer Literate & \\
\hline Perceptive & \\
\hline
\end{tabular}

\section{Generation of Factor Scores}

Factor scores were generated to reduce the subset of variables submitted for further analysis. Consistent with Hunt et al. (2004), factor scores were created by summing the raw scores for each item that loaded on the factor and dividing by the number of items. Participants with missing data were included in the analysis if they had no more than two missing items per factor. In these cases, summing the available number of items and dividing by them created factor scores. This procedure is a consistent and acceptable method for summarizing data (Gorsuch, 1983; Harman, 1976). This method of computing factor scores has a distinct advantage over regression constructed factor scores in that the original metric of the rating scale is preserved. This allows the researcher to stay closer to the true form of the data and makes the information more readily interpretable. Table 1 shows the items that loaded on the Professionalism and Personability factors through factor analysis. Cronbach's alpha, a measure of how well a set of items measures a latent construct, was computed for each factor across each source. Cronbach's alpha for Professionalism across the five sources ranged from .88 to .9; for Personability it ranged from .85 to .91. Thus, each factor demonstrated strong inter-item consistency across sources.

\section{RESULTS}

\section{Descriptive Statistics}

Table 2 breaks down the sample by self-reported major, age, and whether the student had taken accounting in high school. The sample consisted of 199 men and 145 women. The mean age for the total sample was 22.38 $(\mathrm{SD}=5.61)$ and $21.73(\mathrm{SD}=4.31)$ and $23.26(\mathrm{SD}=6.91)$ for men and women, respectively. Accounting majors represented the oldest group, with a mean age of $25.65(\mathrm{SD}=7.45)$. 
The largest group of respondents decided on a major during their first two years of college $(n=150)$, with many students deciding while in high school $(\mathrm{n}=85)$, after high school but before college $(\mathrm{n}=50)$, and during their junior or senior year $(n=53)$. Approximately $40 \%$ of accounting majors decided before starting college. For accounting majors, having taken accounting in high school was significantly related to selecting a major before attending college $\left(\mathrm{X}^{2}(1, \mathrm{~N}=66)=11.979, p=.001\right)$. By examining the 338 categorical responses to the question "how long ago did you decide on a major," we determined that $80.8 \%$ decided after the Enron scandal was publicized.

\begin{tabular}{|c|c|c|c|c|}
\hline \multicolumn{5}{|c|}{$\begin{array}{c}\text { Table } 2 \\
\text { Demographic Information }\end{array}$} \\
\hline Majors & Age & Major & Percentage of sample & $\begin{array}{l}\text { Took High School } \\
\text { Accounting }\end{array}$ \\
\hline Accounting & $\begin{array}{l}25.65 \\
(7.45)\end{array}$ & 69 & 20.18 & $58.0 \%$ \\
\hline Finance & $\begin{array}{l}20.42 \\
(1.35)\end{array}$ & 19 & 5.55 & $52.6 \%$ \\
\hline Marketing & $\begin{array}{l}20.92 \\
(4.96)\end{array}$ & 48 & 14.04 & $29.2 \%$ \\
\hline Management & $\begin{array}{l}22.64 \\
(6.45)\end{array}$ & 58 & 16.96 & $34.5 \%$ \\
\hline $\begin{array}{l}\text { Information } \\
\text { Management. }\end{array}$ & $\begin{array}{l}23.17 \\
(3.43)\end{array}$ & 12 & 3.51 & $16.7 \%$ \\
\hline Non-business & $\begin{array}{l}21.88 \\
(4.61)\end{array}$ & 83 & 24.56 & $31.0 \%$ \\
\hline Business Undecided & $\begin{array}{l}20.53 \\
(2.74)\end{array}$ & 43 & 12.57 & $11.1 \%$ \\
\hline $\begin{array}{l}\text { Non- business, } \\
\text { Undecided }\end{array}$ & $\begin{array}{l}20.00 \\
(1.41)\end{array}$ & 9 & 2.63 & $20.0 \%$ \\
\hline Total & $\begin{array}{l}22.38 \\
(5.61)\end{array}$ & 341 & 100.00 & \\
\hline
\end{tabular}

Note: The total number of students above is less than the 344 reported earlier, because three students did not report age and two did not report major

\section{Overall Impressions, Sources of Impressions and Differences among Majors}

Overall impression scores. ANOVAs were performed to determine between-major differences in overall (global) impressions of accountants (impressions from the four individual sources and any others). The independent variable was major, and the dependent variables were the impressions for each source. Personal knowledge of accountants was significant $(\mathrm{F}(7,271)=2.698,<.01)$, as was accounting classes taken $(\mathrm{F}(7,259)=3.884, \mathrm{p}<.001)$.

Tukey's Least Significant Difference (LSD) tests were performed to follow up ANOVA results to determine where statistically significant between-groups differences existed. These analyses examined research questions 1a (What impressions do students have from various sources, including overall?) and $1 \mathrm{~b}$ (What differences exist in impressions between accounting majors and students in other disciplines?). The results of the posthoc comparisons, presented in Table 3, show that the overall views of accountants were lower for all majors except finance and non-business undecided students, as compared to accounting $(p<.01)$.

A similar pattern was found for two specific sources of impressions, accountants known and accounting classes. However, significant differences existed between accounting majors and only marketing and management majors for impressions from news reports and marketing for movies/TV. For most majors, impressions of accountants from accounting courses were lower than impressions derived from accountants known. Impressions from news reports and movies/TV had the lowest scores, but were still around the midpoint of the 7-point scale. (See Table 3). 
Factor scores. To examine research questions $1 \mathrm{a}$ and $1 \mathrm{~b}$ by factor scores, an ANOVA was performed, with student major as the independent variable and impressions from each source as the dependent variables. Significant differences were followed with posthoc Tukey's LSD tests. For the Professionalism factor, significant differences existed among majors for accountants known $(p=.01)$, accounting classes taken $(p=.065)$, and from all sources $(p$ $=.048$ ). No sources provided significant differences in the Personability factor. Although the Professionalism factor had relatively high scores (over 5 on the 7-point Likert scale) across the five sources of impressions, the Personability factor scores were lower, typically around the midpoint of 4. (See Tables 4 and 5.)

For most majors, the highest means were for impressions from accountants known; the lowest were for movies/TV and news reports. For the Professionalism factor, accounting majors held significantly more positive (using LSD posthoc comparisons tests) impressions from movies/TV compared to those for marketing and information management majors. Marketing majors had significantly less positive impressions for accountants known and overall. Higher scores are considered more positive. Some components of Professionalism, such as thorough and attentive to detail, may be part of an accounting stereotype. However, we believe that they are positive qualities that are required, along with many others, of today's accountants.

In the Personability factor, accounting majors reported significantly lower impressions from each individual source and overall than did finance majors. Accounting majors also reported significantly lower impressions than did management, information management, non-business majors, and non-business undecided students (movies/TV), management and information systems majors (news reports), and management majors (accountants known).

Participants indicated other sources of impressions. The most frequently mentioned were family (reported by 30 students), friends (20), and books/magazines/internet (13).

Importance of individual sources on overall impressions. In order to evaluate how individual impression sources may influence overall impressions (research question 1d), we regressed the four sources on the overall impression score. This yielded an $\mathrm{R}^{2}$ of .621 , explaining $62.1 \%$ of the variance. Accounting classes had the highest standardized Beta coefficients (.446), followed by personal knowledge of accountants (.305), fictional movies/TV shows (.237) and news reports (.201). These results are shown in Table 6.

\section{Gender Differences}

\begin{tabular}{|c|c|c|c|c|c|}
\hline \multicolumn{6}{|c|}{$\begin{array}{c}\text { Table } 3 \\
\text { Mean Overall Impressions of Accountants }\end{array}$} \\
\hline Major & Movies/TV & News Reports & $\begin{array}{c}\text { Accountants } \\
\text { Known }\end{array}$ & $\begin{array}{c}\text { Accounting. } \\
\text { Courses }\end{array}$ & Overall \\
\hline Accounting & 4.67 & 4.32 & 5.88 & 5.66 & 5.54 \\
\hline Finance & 4.69 & 4.53 & 5.65 & 5.77 & 5.22 \\
\hline Marketing & $3.98 * *$ & $3.70 * *$ & $5.15 * * *$ & $4.38 * * * *$ & $4.46 * * * *$ \\
\hline Management & $4.11 * *$ & 3.89 & 5.58 & $4.85 * * *$ & $4.94 * * *$ \\
\hline $\begin{array}{c}\text { Information } \\
\text { Management }\end{array}$ & 4.25 & 3.91 & $4.92 * * *$ & $4.40 * * *$ & $4.67 * * *$ \\
\hline Non- Business. & 4.27 & 4.09 & $5.39 * *$ & $5.04 * *$ & $4.95 * * * *$ \\
\hline $\begin{array}{c}\text { Business, } \\
\text { Undeclared } \\
\end{array}$ & 4.38 & 4.13 & $4.86 * * * *$ & 5.44 & $4.80 * * * *$ \\
\hline $\begin{array}{c}\text { Non-Business, } \\
\text { Undeclared }\end{array}$ & 4.78 & 4.50 & 5.86 & $4.29 * *$ & 5.11 \\
\hline \multicolumn{6}{|c|}{$\begin{array}{l}\text { Means are on a scale from } 1-7(7=\text { most positive impression). } \\
\text { Significance from least significant difference (LSD) multiple comparisons tests are as follows: } \\
* \text { Significant at } .1 \text { level } \\
* * \text { Significant at } .05 \text { level } \\
* * * \text { Significant at } .01 \text { level } \\
* * * * \text { Significant at } .001 \text { level } \\
\text { All significance levels are for differences between the impression scores of accountants and tho }\end{array}$} \\
\hline
\end{tabular}


An ANOVA was performed to determine the effect of gender (independent variable) on impressions of accountants (dependent variable) (research question 2). Women demonstrated significantly more positive impressions of accountants from personal knowledge $(\mathrm{F}(1,277)=5.40, p<.021)$, accounting classes $(\mathrm{F}(1,265)=$ $3.440, p<.065)$, and overall $(\mathrm{F}(1,326)=3.946, p<.048)$. See Table 7.

Another ANOVA was performed to determine gender differences (independent variable) by factor score (dependent variables, Professionalism \& Personability) across sources of information. Results showed that women had significantly more positive impressions of accountants from movies/TV $(\mathrm{F}(1,319)=9.905, p<.002)$, news reports $(\mathrm{F}(1,306)=3.373, p<.067)$, and accountants known $(\mathrm{F}(1,235)=7.856, p<.005)$ for the Professionalism factor and for accountants known $(\mathrm{F}(1,233)=6.801, p<.010)$ for Personability. No statistically significant gender differences existed in knowledge (research question 3e), time (such as in high school) or age when deciding on a major.

\section{Level of Knowledge}

By source, overall and differences by major. ANOVAS were performed on level of knowledge (dependent variable) by major (independent variables) in order to test research questions 3a (what knowledge do students have about accountants from various sources?) and $3 \mathrm{~b}$ (how does it differ across majors?). Significant differences were followed-up with LSD posthoc analyses. News reports $(\mathrm{F}(7,309)=2.463, \mathrm{p}<.018)$, accounting classes $(\mathrm{F}(7,262)=$ $1.979, \mathrm{p}<.058)$, and overall $(\mathrm{F}(7,316)=1.751, \mathrm{p}<.097)$ were significant. For all sources, finance majors reported significantly higher levels of knowledge than did accounting majors. Accounting majors reported the lowest levels of knowledge from movies/TV and news reports of any student group. See Table 8.

\begin{tabular}{|c|c|c|c|c|c|}
\hline \multicolumn{6}{|c|}{$\begin{array}{c}\text { Table } 4 \\
\text { Mean Impressions of Accountants }- \text { Factor One (Professionalism) }\end{array}$} \\
\hline Major & Movies/TV & News Reports & $\begin{array}{l}\text { Accountants } \\
\text { Known }\end{array}$ & $\begin{array}{l}\text { Accounting. } \\
\text { Courses }\end{array}$ & Overall \\
\hline Accounting & 5.60 & 5.15 & 5.90 & 5.59 & 5.66 \\
\hline Finance & 5.62 & 5.38 & 5.96 & 5.80 & 5.73 \\
\hline Marketing & $4.12 * *$ & 4.84 & $5.36 * *$ & 5.23 & $5.30^{* * *}$ \\
\hline Management & 5.64 & 5.04 & 6.02 & 5.34 & 5.50 \\
\hline $\begin{array}{l}\text { Information } \\
\text { Management }\end{array}$ & $5.09 * *$ & 5.09 & 5.57 & 5.30 & 5.27 \\
\hline Non-Business & 5.44 & 5.16 & 5.25 & 5.30 & 5.52 \\
\hline $\begin{array}{l}\text { Business } \\
\text { Undeclared }\end{array}$ & 5.39 & 5.08 & 5.81 & 5.44 & 5.43 \\
\hline $\begin{array}{c}\text { Non-Business, } \\
\text { Undeclared }\end{array}$ & 5.36 & 4.82 & 6.04 & 5.03 & 5.28 \\
\hline \multicolumn{6}{|c|}{$\begin{array}{l}\text { Means are on a scale from 1-7 (7=most positive impression). } \\
\text { Significance from least significant difference (LSD) multiple comparisons tests are as follows: } \\
* \text { Significant at } 1 \text { level } \\
* * \text { Significant at } .05 \text { level } \\
\text { All sionificance levels ar for differences hetween the }\end{array}$} \\
\hline
\end{tabular}

\section{Relative Importance of Sources of Knowledge}

Research question 3c examined the effect of various sources of knowledge on overall knowledge. The four individual sources of knowledge were regressed on overall knowledge, resulting in an $\mathrm{R}^{2}$ of .720 , accounting for $72 \%$ of the variance. Accounting courses were the most influential source of knowledge, with a standardized Beta oefficient of .370, followed by personal knowledge of accountants (.322), news reports (.259), and movies/TV (.159). All standardized Beta are statistically significant. Table 9 summarizes the results. 


\section{Relationship of Knowledge to Impressions}

In order to evaluate the relationship between knowledge and impressions (research question 3d), five regressions of a source of impressions on the related source of knowledge were performed. All F-tests were statistically significant. The regression of impressions derived from movies/TV onto knowledge from movies/TV produced $\left(\mathrm{F}(1,299)=33.462, p<.0001 ; \mathrm{R}^{2}\right.$ Adjusted $=.098$, standardized $\left.\beta=.317, p<.0001\right)$. Similar analyses yielded the following: impressions and knowledge from news reports $\left(\mathrm{F}(1,303)=6.236, p=.013\right.$; $\mathrm{R}^{2}$ Adjusted= .017 , standardized $\beta=.142, p<.013)$, accountants known $\left(\mathrm{F}(1,268)=91.670, p<.0001 ; \mathrm{R}^{2}\right.$ Adjusted $=.252$, standardized $\beta=.505, p<.0001)$, accounting courses $\left(\mathrm{F}(1,252)=56.375, p=.0001 ; \mathrm{R}^{2}\right.$ Adjusted $=.18$, standardized $\beta=.428, p<.0001)$, and overall $\left(\mathrm{F}(1,315)=54.164, p<.0001 ; \mathrm{R}^{2}\right.$ Adjusted $=.144$, standardized $\beta=$ $.383, p<.0001)$.

\begin{tabular}{|c|c|c|c|c|c|}
\hline \multicolumn{6}{|c|}{$\begin{array}{c}\text { Table } 5 \\
\text { Mean Impressions of Accountants }- \text { Factor Two (Personability) }\end{array}$} \\
\hline Major & Movies/TV & News Reports & $\begin{array}{l}\text { Accountants } \\
\text { Known }\end{array}$ & $\begin{array}{l}\text { Accounting. } \\
\text { Courses }\end{array}$ & Overall \\
\hline Accounting & 3.33 & 3.38 & 4.25 & 3.93 & 3.96 \\
\hline Finance & $4.06 * *$ & $4.17 * * *$ & $4.89 *$ & $4.61 *$ & $4.52 *$ \\
\hline Marketing & 3.38 & 3.68 & 4.04 & 3.70 & 3.79 \\
\hline Management & $3.81 *$ & 3.74 & $4.61 *$ & 3.97 & 4.11 \\
\hline $\begin{array}{l}\text { Information } \\
\text { Management. }\end{array}$ & $3.98 *$ & $3.80 *$ & 3.82 & 3.88 & 3.74 \\
\hline Non-Business & $3.67 *$ & $3.70 *$ & 4.36 & 4.06 & 3.87 \\
\hline $\begin{array}{l}\text { Business, } \\
\text { Undeclared }\end{array}$ & 3.73 & 3.58 & 4.59 & 3.88 & 3.74 \\
\hline $\begin{array}{l}\text { Non-Business, } \\
\text { Undeclared }\end{array}$ & $4.39 * *$ & 3.99 & 4.54 & 4.23 & 4.17 \\
\hline \multicolumn{6}{|c|}{$\begin{array}{l}\text { Means are on a scale from } 1-7(7=\text { most positive impression). } \\
\text { Significance from least significant difference (LSD) multiple comparisons tests are as follows: } \\
* \text { Significant at } .1 \text { level } \\
* * \text { Significant at } .05 \text { level } \\
* * * \text { Significant at } .01 \text { level }\end{array}$} \\
\hline
\end{tabular}

\begin{tabular}{|c|c|c|c|}
\hline \multicolumn{4}{|c|}{$\begin{array}{c}\text { Table } 6 \\
\text { Summary of Simultaneous Regression Analysis for Variables Predicting Impressions Based on Four Sources }(\mathbf{N}=201)\end{array}$} \\
\hline Variable (Impressions From) & B & SE B & $\beta$ \\
\hline Movies - TV (fiction) & .175 & .037 & $.237 * * *$ \\
\hline News Reports & .138 & .034 & $.201 * * *$ \\
\hline Personal Knowledge of Accounts & .243 & .038 & $.305 * * *$ \\
\hline Accounting Classes & .316 & .033 & $.446 * * *$ \\
\hline
\end{tabular}

\begin{tabular}{|c|c|c|c|c|c|}
\hline \multicolumn{6}{|c|}{$\begin{array}{c}\text { Table } 7 \\
\text { Impressions of Accountants from Various Sources by Gender }\end{array}$} \\
\hline Gender & Movies/TV & News Reports & $\begin{array}{l}\text { Accountants } \\
\text { Known }\end{array}$ & $\begin{array}{l}\text { Accounting. } \\
\text { Courses }\end{array}$ & Overall \\
\hline Male & 4.23 & 3.98 & 5.28 & 4.94 & 4.89 \\
\hline Female & 4.47 & 4.21 & $5.65 * *$ & $5.30 *$ & $5.13 * *$ \\
\hline \multicolumn{6}{|c|}{$\begin{array}{l}\text { Means are on a scale from 1-7 (7=most positive impression). } \\
\text { Significance from ANOVA is as follows: } \\
\text { *Significant at } .1 \text { level } \\
\text { **Significant at } .05 \text { level } \\
\text { All significance levels are for differences between the impression scores of accountants and those of other majors based upon } \\
\text { Tukey's LSD posthoc tests. }\end{array}$} \\
\hline
\end{tabular}




\begin{tabular}{|c|c|c|c|c|c|}
\hline \multicolumn{6}{|c|}{$\begin{array}{c}\text { Table } 8 \\
\text { Level of Knowledge of Accountants from Various Sources }\end{array}$} \\
\hline Major & Movies/TV & News Reports & $\begin{array}{l}\text { Accountants } \\
\text { Known }\end{array}$ & $\begin{array}{l}\text { Accounting. } \\
\text { Courses }\end{array}$ & Overall \\
\hline Accounting & 3.48 & 3.73 & 5.07 & 4.98 & 4.85 \\
\hline Finance & $4.29 *$ & $5.21 * * * *$ & $5.88 *$ & $5.93 * *$ & $5.44 *$ \\
\hline Marketing & 3.66 & 4.24 & 4.79 & 4.68 & 4.47 \\
\hline Management & 3.86 & 3.86 & 4.94 & 5.15 & 4.58 \\
\hline Information Management. & 3.91 & $4.80 *$ & 4.55 & 5.13 & 5.00 \\
\hline Non-Business & 3.82 & 3.93 & 4.88 & $4.22 *$ & 4.51 \\
\hline Business Undeclared & 3.90 & $4.31 *$ & 4.71 & 4.97 & 4.57 \\
\hline Non-Business, Undeclared & 4.33 & 3.89 & 5.71 & 5.00 & 5.38 \\
\hline \multicolumn{6}{|c|}{$\begin{array}{l}\text { Means are on a scale from 1-7 (7=highest level of knowledge). } \\
\text { Significance from least significant difference (LSD) multiple comparisons tests are as follows: } \\
* \text { Significant at } .1 \text { level } \\
* * \text { Significant at } .05 \text { level } \\
* * * \text { Significant at } .01 \text { level } \\
* * * * \text { Significant at } .001 \text { level } \\
\text { All significance levels are for differences between the impression scores of accountants and those of other majors. }\end{array}$} \\
\hline
\end{tabular}

\begin{tabular}{|c|c|c|c|}
\hline \multicolumn{5}{|c|}{ Table 9 } \\
Summary of Simultaneous Regression Analysis for Variables Predicting Overall Knowledge Impressions from \\
Knowledge of Four Factors (N = 204)
\end{tabular}

\section{DISCUSSION}

\section{Conclusions}

This research examined three broad research questions. First, what impressions do students have of accountants at the time of selecting a major and do impressions differ by major? The high $\mathrm{R}^{2} \mathrm{~s}$ resulting from regressing overall impressions on each impression source, along with few participants' naming other sources, indicated that the research identified major sources of impressions. All majors held positive impressions of accountants from all sources, even news reports, which would include descriptions of financial scandals. These results bode well for public acceptance of accountants as competent and credible information providers. High scores for professionalism are important in that if accountants are considered incapable of performing their duties properly; their personability may be of little concern.

However, the considerably lower factor scores for Personability are problematic for the profession. While this result is consistent with Hunt et al. (2004), mean scores of accounting students' views of accountants' Personability were less positive in the current study. Poor perceived Personability may impede career success. Accounting majors' impressions were similar to those of other majors, indicating that they too view accountants in a somewhat stereotypical manner as competent but less able to interact well with others. This may provide some support for Albrecht and Sack's (2000) assertion that students major in accounting without adequately understanding the qualities needed in a successful accountant. Reducing the negative aspects (Personability) of the stereotype while retaining the positive ones (Professionalism) is necessary to attract future business leaders into the accounting profession.

The finding that accounting courses are highly significant in determining overall impressions may partially explain Chen et al.'s (2005) conclusion that one's first accounting course is the most important factor affecting 
choice of an accounting major. This finding also adds importance to the more positive students' impressions of accountants from accounting courses than in Hunt et al. (2004). Accounting education may be heeding Albrecht and Sack (2000)'s call to improve introductory accounting courses. However, the conclusion that accountants are generally viewed more favorably for professional than personal skills indicates the need for accounting education to stress the leadership and communication skills required of today's accountants. Putting the most engaging teachers in introductory accounting courses may help improve students' impressions of accountants. Personal knowledge of accountants' resulting in higher impressions of accountants than did accounting courses implies that educators should provide opportunities for direct student contact with accountants.

The second broad research question dealt with gender differences in impressions. Women's significantly more favorable impressions of accountants known in both Professionalism and Personability factors may partially explain females' comprising a higher percentage of accounting students in recent years. These higher impressions were not due to differences in knowledge or time of selecting a major; these differences were insignificant. These limited findings may suggest that accounting scandals have not reduced women's interest in majoring in accounting. This in turn should lead to continued progress by women into high levels in the accounting field. However, universities interested in achieving more equality of gender in its accounting majors may need to look for ways to make accountants seem more interesting and exciting to male students.

The final major research issue dealt with students' level of knowledge of accountants when selecting a major. Accounting majors reported lower levels of knowledge of news reports and movies/television than did other majors. This may indicate that accounting majors did not notice and discount such reports, but were unaware of them.

Finance majors reported much higher impressions of accountants than in Hunt et al. (2004). This should indicate respect for accountants by a major group of future colleagues. The fact that those with high knowledge and impressions of accountants rejected accounting may reflect the importance of job-related factors, such as travel and working hours, in major choice.

An important result was the statistically significant correlations between knowledge and impressions from all sources. The more knowledge students obtained, the less likely they were to rely on negative stereotypes. For most majors, accounting courses taken and accountants known provided the major sources of knowledge, consistent with these two sources having the highest effect on impressions. These results place additional emphasis on the need to accurately portray accountants in accounting courses and to provide opportunities for students to meet accountants.

The finding that students who took a high school accounting course were significantly more likely to make early decisions to major in accounting implies the necessity for the profession to provide information on current expectations of accountants to high school students, teachers, and advisors. For example, 12 state CPA societies offer summer accounting programs, each attracting 20-45 students per year. A successful student program in Tennessee may be expanded to include high school educators (Frasier, Galbreath, \& Moore, 2006). However, additional programs reaching a wider audience are needed.

\section{Limitations of the Study}

There are several limitations of this study. The study was conducted at one medium sized, predominantly Caucasian public university. Some majors were represented by relatively small numbers of participating students. This limits the generalizability of the results.

Another possible problem lies with the self-reported level of knowledge, which accounting majors might inflate to make themselves appear to have made a more informed major decision. However, this does not appear to be an issue, since accounting majors reported low knowledge of movies/TV and news reports.

Participants reported their impressions and levels of knowledge of accountants at the time of selecting a major. Those who had selected a major some time earlier might have reconstructed such information by relying 
somewhat on current impressions.

\section{Future Research}

Future research could involve surveying high school students to help determine to what extent impressions of accountants from accounting courses originated in high school as opposed to college. Future research could obtain impressions from students from a wide variety of colleges and universities. Examining the effects of race or ethnicity on impressions of accountants could provide information useful to the profession and educational institutions in their attempts to attract more minorities to accounting.

\section{AUTHOR INFORMATION}

Steven C. Hunt is an associate professor of accountancy at Western Illinois University, where he has taught auditing and financial accounting for 11 years. He has published research in a number of journals, including the Journal of Accounting Literature, the Accounting Forum, and the Journal of Accounting Education. He received his $\mathrm{PhD}$ from the University of Florida and Bachelors and Masters degrees from the University of Georgia. Before pursuing an academic career, he obtained his CPA certificate and worked as an auditor for a large public accounting firm.

Robert C. Intrieri, PhD, is an Associate Professor in the Department of Psychology at Western Illinois University. He has conducted more than 30 research studies related to aging and the study of emotion, life satisfaction, and perceived stress among differing age groups and has prepared numerous presentations and publications based on this research. He currently holds over 20 peer-reviewed publications, book chapters, and monographs. He is a member of Sigma Xi, The Scientific Research Society, and Phi Kappa Phi Honor Society, the American Psychological Association, and the Gerontological Society of America.

Anthony Falgiani, JD, CMA, is an Associate Professor, Emeritus, at Western Illinois University - Quad Cities, where he taught tax and managerial accounting for 19 years.

Marie Papini is a 2005 graduate of Western Illinois University with a Bachelor of Science degree in Psychology with a minor in Human Resource Management. Papini was a member of the Honors College and was active in Psi Chi (Psychology Honors Society), Mortar Board (National Honors Society), and Hotline (a paraprofessional crisis line service). She obtained her Masters degree in School Counseling in 2007 from Mississippi State University, where she was an active member of Chi Sigma Iota. Papini is a Nationally Certified Counselor (NCC) and works as a School Counselor in Watertown, TN.

\section{REFERENCES}

1. Albrecht, W. Steve and Robert J. Sack, Accounting Education: Charting the Course Trough a Perilous Future, American Accounting Association Accounting Education Series, Vol. 16, 2000.

2. Ameen, Elsie .C., Daryl M. Guffey, and Jeffrey J. McMillan, Gender Differences in Determining the Ethical Sensitivity of Future Accounting Professionals, Journal of Business Ethics, Vol. 15, No. 5, pp. 591-597, 1996.

3. Beard, Victoria, Popular Culture and Professional Identity: Accountants in the Movies, Accounting, Organizations and Society, Vol. 19, No. 3, pp. 303-318, 1994.

4. Blustein, David L, and Douglas C. Strohmer, Vocational Hypothesis Testing in Vocational Decisionmaking, Journal of Vocational Behavior, Vol. 31, No. 1, pp. 45-62, 1987.

5. Bougen, Philip D., Joking apart: The Serious Side to the Accountant Stereotype, Accounting, Organizations and Society, Vol. 19, No. 3, pp. 319-335, 1994.

6. Chen, C. Clement, Keith T. Jones, and D. David McIntyre, A Reexamination of Factors Important to Selection of Accounting as a Major, Accounting and the Public Interest, Vol. 5, pp. 14-31, 2005.

7. Coate, C.J., Michael C. Mitschow, and Michael D. Schinski, What Students Think of CPAs: Is the Stereotype Alive and Well? CPA Journal, Vol. 73, No. 8, pp. 52-55, 2003. 
8. Cohen, Jeffrey and Dennis Hanno, An Analysis of Underlying Constructs Affecting the Choice of Accounting as a Major, Issues in Accounting Education, Vol. 8, No. 2, pp. 219-237, 1993.

9. Coleman, Mimi, Jerry Kreuze, and Sheldon Langsam, The New Scarlet Letter: Student Perceptions of the Accounting Profession After Enron, Journal of Education for Business, Vol. 79, No. 3, pp. 134-141, 2004.

10. Cory, Suzanne N., Quality and Quantity of Accounting Students and the Stereotypical Accountant: Is There a Relationship? Journal of Accounting Education, Vol. 10, No. 1, pp. 1-24, 1992.

11. Davidson, Ronald .A. and Lois D. Etherington, Personalities of Accounting Students and Public Accountants: Implications for Accounting Educators and the Profession, Journal of Accounting Education, Vol. 13, No. 3, pp. 425-444, 1995..

12. DeCoster, Don T., Mirror, Mirror on the Wall, the CPA in the World of Psychology, Journal of Accountancy, Vol. 132, No. 2, pp. 40-45, 1971,.

13. DeCoster, Don T. and John G. Rhode, The Accountant's Stereotype: Real or Imagined, Deserved or Unwarranted, The Accounting Review, Vol. 66, No. 4, pp. 651-664, 1971.

14. Dimnik, Tony and Sandra Felton. The Image of the Accountant in Popular Cinema, Paper presented at the American Accounting Association Annual Meeting, Philadelphia, 2000.

15. Frasier, Charles E., Susan Galbreath, and Perry G. Moore, Accounting Academy: From High School to the Corner Office, Journal of Accountancy, Vol. 201, No. 5, pp. 65-67, 69, 2006.

16. Geiger, Marshall A. and Suzanne Ogilby, The First Course in Accounting: Students' Perceptions and Their Effect on the Decision to Major in Accounting, Journal of Accounting Education, Vol. 18, No. 2, pp. 63$78,2000$.

17. Giacomino, Don E., Ethical Perceptions of Accounting Majors and Other Business Majors: An Empirical Study, Accounting Educators' Journal, Vol. 4, No. 2, pp. 1-26, 1991.

18. Gorsuch, Richard L., Factor Analysis $2^{\text {nd }}$ ed. Hillsdale, NJ: L. Erlbaum Associates, 1983.

19. Gottfredson, Linda S., Circumscription and Compromise: A Developmental Theory of Occupational Aspirations, Journal of Counseling Psychology, Vol. 28, No. 6, pp. 545-579, 1981.

20. Harman, Harry.H., Modern Factor Analysis $3^{\text {rd }}$, revised ed., Chicago: University of Chicago Press, 1976.

21. Hermanson, Dana, Roger Hermanson., and Susan H. Ivancevich, Are America’s Top Business Students Steering Clear of Accounting? The Ohio CPA Journal, Vol. 54, No. 2, pp. 26-30, 1995.

22. Holt, Paul E., Stereotypes of the Accounting Professional as Reflected by Popular Movies, Accounting Students, and Society, New Accountant, Vol. 9, No. 7, pp. 24-25, 1994.

23. Hunt, Steven C., A. Anthony Falgiani, and Robert C. Intrieri, The Nature and Origins of Students' Perceptions of Accountants. Journal of Education for Business, Vol. 79, No. 3, pp. 142-148, 2004.

24. Imada, Andrew S., Clive Fletcher, C., and Anthony Dalessio, Individual Correlates of an Occupational Stereotype: A Reexamination of the Stereotype of Accountants, Journal of Applied Psychology, Vol. 65, No. 4, pp.: 436-439, 1980.

25. Inman, Brent C., Audre Wenzler, and Peter D. Wickert, Square Pegs in Round Holes: Are Accounting Students Well-suited to Today's Accounting Profession? Issues in Accounting Education, Vol. 4, No. 1, pp. 29-47, 1989.

26. Judd, Charles C.M. and Bernadette Park, Definition of Assessment of Accuracy in Social Stereotypes, Psychological Review, Vol. 100, pp. 109-128, 1993.

27. Lips, Hilary .M. Gender- and Science-related Attitudes as Predictors of College Students' Academic Choices. Journal of Vocational Behavior, Vol. 40, No. 1, pp. 62-81, 1992.

28. Marriott, Pru and Neil Marriott, Are we Turning Them on? A Longitudinal Study of Undergraduate Accounting Students' Attitudes Towards Accounting as a Profession. Accounting Education, Vol. 12, No. 2, pp. 113-133, 2003.

29. Myers, Randy, How CFOs Stretch Boundaries, Journal of Accountancy, Vol. 193, No. 5, pp. 75-82, 2002.

30. Paolillo, Joseph G. and Ralph W. Estes. An Empirical Analysis of Career Choice Factors among Accountants, Attorneys, Engineers, and Physicians, The Accounting Review, Vol. 57, No. 4, pp. 785-793, 1982.

31. Parker, Lee, Goodbye, Number Cruncher! Australian CPA, No. 1, pp. 50-52, 2000.

32. Radtke, Robin R., The Effects of Gender and Setting on Accountants' Ethically Sensitive Decisions, Journal of Business Ethics, Vol. 24, No. 2, pp. 299-312, 2000.

33. Saemann, Georgia P. and Karen .J. Crooker, Student Perceptions of the Profession and its Effect on Decisions to Major in Accounting, Journal of Accounting Education, Vol. 17, No. 1, pp. 1-22, 1999. 
34. Saemann, Georgia P., Karen .J. Crooker, and Laura J. Kreissl. Perceptions of the Profession: Are We Succeeding in Casting a Wider Net? Advances in Accounting Education: Teaching and Curriculum Innovations, Vol. 8, pp. 167-195, 2007.

35. Sankaran, Siva and Tung Bui, Ethical Attitudes among Accounting Majors: An Empirical Study, Journal of American Academy of Business, Cambridge, Vol. 3, No. 1/2, pp. 71-77, 2003.

36. Siegel, Gary, James E. Sorensen and Sandra Richtermeyer. Part 1: Are You a Business Partner? Strategic Finance Vol. 85, No. 3, pp. 38-43, 2003.

37. Skrypnek, Berna J. and Mark Snyder, On the self-perpetuating nature of stereotypes about women and men. Journal of Experimental Social Psychology, Vol. 18, No. 3, 277-291, 1982.

38. Smith, Malcolm and Susan Briggs, From bean-counter to action hero: Changing the image of the accountant, Management Accounting-London, Vol. 77, No. 1, pp: 28-30, 1999.

39. St. Pierre, Kent E., E.S. Nelson, and Alexander L. Gabbin, A study of the ethical development of accounting majors in relation to other business and nonbusiness disciplines, The Accounting Educators' Journal, Vol. 3, pp. 23-351, 1990.

40. Tie, Robert. The profession's roots. Journal of Accountancy, Vol. 196, No. 5, pp. 57-59, 2003.

41. Vigilante, Barbara, Women at full throttle, Journal of Accountancy, Vol. 200, No. 12, pp. 76-77, 2005. 
NOTES 